\title{
Labour Market Disparity, Poverty, and Inequality in Urban China
}

Fei Guo et Zhiming Cheng

\section{(2) OpenEdition}

\section{Journals}

Édition électronique

URL : http://journals.openedition.org/chinaperspectives/5334

DOI : 10.4000/chinaperspectives.5334

ISSN : 1996-4617

Éditeur

Centre d'étude français sur la Chine contemporaine

Édition imprimée

Date de publication : 15 décembre 2010

ISSN : 2070-3449

\section{Référence électronique}

Fei Guo et Zhiming Cheng, "Labour Market Disparity, Poverty, and Inequality in Urban China », China

Perspectives [En ligne], 2010/4 | 2010, mis en ligne le 01 décembre 2013, consulté le 28 octobre 2019 URL : http://journals.openedition.org/chinaperspectives/5334 ; DOI : 10.4000/chinaperspectives.5334 
L

\title{
Labour Market Disparity,
}

\section{Poverty, and Inequality in}

Urban China

\author{
FEI GUO AND ZHIMING CHENG
}

ABSTRACT: This paper examines poverty and income inequality in urban China by analysing recent survey data collected in four of the largest Chinese cities ${ }^{(1)}$. Using a number of quantitative measurements, including poverty indices and Gini coefficients, the paper investigates income poverty and inequality among three groups, namely urban locals, urban migrants, and rural migrants. The results strongly suggest that urban poverty and inequality are a serious issue and that rural migrants have become a major segment in the urban poor class. The results are expected to contribute to the debate on how to improve public policy on poverty alleviation, which currently focuses only on officially registered urban locals.

\section{Introduction}

1 The Chinese economy has been experiencing tremendous growth since economic reform commencing in the late 1970s. Agrarian reform has transformed the rural areas, which were under the shadow of widespread poverty and disadvantaged by urban-oriented state development policies, into the most successful case of combating extreme monetary poverty. ${ }^{(2)}$ As measured by the World Bank's (American) dollar-a-day poverty standard based on Purchasing Power Parity (PPP) at 1993 international prices, ${ }^{(3)}$ China's remarkable increase in per capita income has fuelled an equally remarkable decrease in the extreme poverty rate from 74 percent at the beginning of the reform to 15 percent in 2004; in other words, more than 500 million people moved out of poverty. ${ }^{(4)}$ In particular, China has been praised for meeting the foremost of the Millennium Development Goals - one of which is to halve the 1990 poverty incidence - 14 years ahead of the 2015 target for developing countries, and for providing a plausible model for African countries that have been struggling with poverty. ${ }^{(5)}$ Aside from these promising anti-poverty outcomes, social disparity and differentiation, among which inequality and urban poverty are arguably the most severe, have emerged as relatively new socio-economic issues in China, which was once an extremely egalitarian or collectively poor society under the Mao regime. One of the reasons for the near nonexistence of urban paupers was the ideological dominance of communism, which discouraged personal income incentives but guaranteed lifelong employment and substantial fringe benefits including housing, education, healthcare, and pensions through a danwei-style (work unit) organisational system that enclosed the vast majority of urban residents under the shelter of the state sector. ${ }^{(6)}$ Indeed, in the late 1980s, it

1. This paper is part of an Australian Research Council (ARC) Discovery project entitled Migrant Labour in Large Chinese Cities. The authors would like to acknowledge the constructive comments and useful suggestions from two anonymous referees and the instrumental contributions by Professor Graeme Hugo at the University of Adelaide and Professor Yuan Xin at Nankai University in the project. The normal disclaimer applies.

2. For example, see the following research: Shenggen Fan, Linxiu Zhang, and Xiaobo Zhang, "Reforms, Investment, and Poverty in Rural China," Economic Development and Cultural Change, vol. 52, no. 2, 2004, pp. 395-421; Jyotsna Jalan and Martin Ravallion, "Is Transient Poverty Different? Evidence for Rural China," Journal of Development Studies, vol. 36, no. 6, 2000, pp. 82-99; Carl Riskin, "Chinese Rural Poverty: Marginalized or Dispersed?", American Economic Review, vol. 84, no. 2, 1994, pp. 281-284.

3. Purchasing Power Parity is a widely adopted method for estimating the correct value of a currency, which in many cases, may differ from its current market value. See The Economist, "Purchasing Power Parity," retrieved on 18 August 2010 from http://www.economist.com/research/economics/alphabetic.cfm?term=purchasingpowerparity.

4. Refer to World Bank, China Quarterly Update (February 2008), Beijing, World Bank Office, 2008. Earlier estimates before the recently improved estimate of PPP showed a reduction from approximately 64 percent to 10 percent between 1981 and 2004. See David Dollar, "Poverty, Inequality and Social Disparities during China's Economic Reform," World Bank Policy Research Working Paper, no. 4253, 2007.

5. See Martin Ravallion, "Are There Lessons for Africa from China's Success against Poverty?", World Bank Policy Research Working Paper, no. 4463, 2008. The author argues that two lessons stand out from China's experience: first, the importance of productivity growth in smallholder agriculture with the aid of market-based incentives and public support; second, the role of strong leadership and a capable public administration at all levels of government.

6. See David Bray, Social Space and Governance in Urban China: The Danwei System from Origins to Reform, Stanford, Stanford University Press, 2005; Xiaobo Lü and Elizabeth J. Perry (eds.), Danwei: The Changing Chinese Workplace in Historical and Comparative Perspective, Armonk, M.E. Sharpe, 1997; Andrew G. Walder, Communist Neo-Traditionalism: Work and Authority in Chinese Industry, Berkeley, University of California Press, 1988. 
Table 1. Migrant workers and employment in urban China

\begin{tabular}{|c|c|c|c|}
\hline Year & $\begin{array}{l}\text { Rural migrants (millions) } \\
\text { (1) }\end{array}$ & $\begin{array}{l}\text { Urban employment (millions) } \\
\text { (2) }\end{array}$ & $\begin{array}{c}\text { Ratio (\%) } \\
\text { (1) / (2) }\end{array}$ \\
\hline 2000 & 78.49 & 212.74 & 36.9 \\
\hline 2001 & 83.99 & 239.40 & 35.1 \\
\hline 2002 & 104.70 & 247.80 & 42.3 \\
\hline 2003 & 113.90 & 256.39 & 44.4 \\
\hline 2004 & 118.23 & 264.76 & 44.7 \\
\hline 2005 & 125.78 & 273.31 & 46.0 \\
\hline 2006 & 132.12 & 283.10 & 46.7 \\
\hline 2007 & 136.49 & 293.50 & 46.5 \\
\hline 2008 & 145.33 & 302.10 & 48.1 \\
\hline
\end{tabular}

is believed that less than one percent of the urban population was classified as poor, and these were mainly the disabled, widowed, and others who were not affiliated with any danwei, and who were largely looked after by government. ${ }^{(7)}$ The labour market in making and the urban economy in restructuring are the context within which urban poverty and inequality are emerging. Explicitly advancing returns to education and encouraging rural-urban migration, China is a classic example of what the Nobel Prize economist Arthur Lewis suggests: "Development must be inegalitarian because it does not start in every part of the economy at the same time"; ${ }^{(8)}$ or of Deng Xiaoping's blunt words: "Let some people get rich first." Altering the state-led job assignment system typified by low salaries in the state sector, a labour market in which people can look for better jobs and higher pay outside the state sector has been developing since the late 1970s. It is estimated that the wage returns of one additional year of schooling increased from 4 percent to 11 percent between 1988 and 2003, progressively concentrating income distribution among more educated people, ${ }^{(9)}$ although there is mixed evidence as to whether education is necessarily more highly rewarded in China's socialist market economy. ${ }^{(10)}$

All in all, during the transition from centralised planned economy to market economy, urban income has been increasing together with growing inequalities and/or deteriorating urban poverty, as revealed by a number of studies. ${ }^{\text {(II) }}$ Two sub-populations, among others, are unanimously identified as the major sources of new urban poor, namely laid-off workers and rural-urban migrants. ${ }^{(2)}$

Nationally commenced in 1997 after some trials, the stateowned enterprise (SOE) reform (guoyou qiye gaige) and its embedded labour retrenchment have radically swelled the changing social forces. Laid-off workers (xiagang gongren) or the new urban underclass ${ }^{(1)}$ - have been created in the magnitude of hundreds of millions, although the accurate

7. World Bank, China: Strategies for Reducing Poverty in the 1990s, Washington, World Bank, 1992; Zhiyi Guo, "Pinkun shizhi de lilun renshi yu zhongguo de fan pinkun douzheng (Poverty and China's anti-poverty efforts)," Xibei renkou (Northwest Population Journal), vol. 3, 1996, pp. 3-6.

8. W. Arthur Lewis, "Economic Development with Unlimited Supplies of Labour," The Manchester School, vol. 22, no. 2, 1954, pp. 139-191.

9. Refer to the work by David Dollar, op. cit.

10. See a number of works in this research area: Ben Jann, "Comment: Earnings Returns to Education in Urban China: A Note on Testing Differences among Groups," American Sociological Review, vol. 70, no. 5, 2005, pp. 860-864; Haizheng Li, "Economic Transition and Returns to Education in China," Economics of Education Review, vol. 22, no. 3, 2003, pp. 317-328; Zhiqiang Liu, "The External Returns to Education: Evidence from Chinese Cities," Journal of Urban Economics, vol. 61, no. 3, 2007, pp. 542-564; Xiaogang Wu and Yu Xie, "Does the Market Pay Off? Earnings Returns to Education in Urban China," American Sociological Review, vol. 68, no. 3, 2003, pp. 425-442.

11. See extensive research in these areas in the following references: Simon Appleton, Lina Song and Qingjie Xia, "Growing out of Poverty: Trends and Patterns of Urban Poverty in China 1988-2002," World Development, vol. 38, no. 5, 2010, pp. 665-678; Sylvie Démurger, Martin Fournier and Li Shi, "Urban Income Inequality in China Revisited (19882002)," Economics Letters, vol. 93, no. 3, 2006, pp. 354-359; Laura Hering and Sandra Poncet, "Market Access and Individual Wages: Evidence from China," The Review of Economics and Statistics, vol. 92, no. 1, 2010, pp. 145-159; Laura Hering and Sandra Poncet, "Income Per Capita Inequality in China: The Role of Economic Geography and Spatial Interactions," World Economy, vol. 33, no. 5, 2010, pp. 655-679; Shi Li and Hiroshi Sato (eds.), Unemployment, Inequality and Poverty in Urban China, New York, Routledge, 2006; Xubei Luo and Nong Zhu, "Rising Income Inequality in China: A Race to the Top," Policy Research Working Paper, no. 4700, 2008; Xin Meng, Robert Gregory and Guanhua Wan, "Urban Poverty in China and Its Contributing Factors, 1986-2000," Review of Income and Wealth, vol. 53, no. 1, 2007, pp. 167-189; Xin Meng, Robert Gregory and Youjuan Wang, "Poverty, Inequality, and Growth in Urban China, 1986-2000," Journal of Comparative Economics, vol. 33, no. 4, 2005, pp. 710-729; Camelia Minoiu and Sanjay G. Reddy, "Chinese Poverty: Assessing the Impact of Alternative Assumptions," Review of Income and Wealth, vol. 54, no. 4, 2008, pp. 572-596.

12. Generally speaking, the former is disadvantaged by human capital deficit and the latter by institutional constraints. Refer to Fulong Wu, Chris Webster, Shenjing He, and Yuting Liu, China's Urban Poverty, Cheltenham, Edward Elgar, 2010.

13. Dorothy J. Solinger, "The Creation of New Underclass in China and Its Implications," Environment and Urbanization, vol. 18, no. 1, 2006, pp. 177-193. 
number of this group and the true unemployment rate remain a mystery that neither official re-employment nor any other urban poverty statistics can reliably reveal. ${ }^{(1)}$ Nonetheless the urban poor, among whom laid-off/unemployed workers and their families make up the vast majority (90 percent strong), have reached 23.46 million (in 11.41 million households) according to a benefit poverty line of 228 yuan that was equivalent to only around 20 percent of urban mean income. ${ }^{(15)}$

In 2000, the National Bureau of Statistics (NBS) began gathering information on rural-urban migrants through its rural household survey. By 2008, the population of ruralurban migrants had grown to 145 million, approximately 71 percent of whom were concentrated in the more developed eastern region. They have been continually playing an important role in the urban labour market, accounting for 48 percent of urban employment and showing a steady increase over the years (see Table 1). ${ }^{(16)}$ They mainly worked in the construction, manufacturing, and low-tier service sectors, but the authorities in most cities have not granted them full urban citizenship. ${ }^{(17)}$ In fact, they live in a long-standing dual system that has imposed institutional bias on them through the hukou (household registration) system. ${ }^{(18)}$ Comparisons between labour migrants and urban residents empirically and theoretically reveal that institutional barriers have been decisive factors detrimental to their well-being. ${ }^{(19)}$ As a result, rural-urban migrants without urban hukou have contributed to another major group of urban poor.

An income poverty rate of 15.2 percent was estimated for rural-urban migrants using NBS survey data of $3,600 \mathrm{mi}-$ grants from 31 cities in 1999, while a poverty rate of 10.3 percent was estimated for local residents using NBS urban household survey data from the same year. ${ }^{(20)}$ Analysis of more recent data from the China Income Distribution Survey in six provinces in 2002 reveals that poverty rates were 3 percent for locals and 6 percent for migrants if defined by local official benefit poverty lines, or 6 percent for locals and 16 percent for migrants if a higher line was applied. ${ }^{(21)}$ In these studies, incomes of locals were based on self-recorded diaries while those of migrants were based on one-off reports when filling out the questionnaire. The former two studies excluded zero-income household and the latter excluded urban migrants who were likely to have higher income. Although the biases tended to be acceptable, these analyses may have overstated the relative poverty rate of migrants to locals and underestimated urban-rural income differences. ${ }^{(22)}$ Even with these research efforts, only the tip of the iceberg has been revealed in media and research due to the lack of accuracy and availability of data and limited coverage in existing literature. For instance, little is known about inter-city migrants who also hold urban hukou, even though this is also a sizeable group. ${ }^{(23)}$ Moreover, research is inadequate regarding poverty and inequality among various types of migrants and their well-being relative to the other urban residents.

In an attempt to overcome some of these limitations and to fill gaps in the current literature, we recently carried out a study that included three sub-groups. The first group is ruralurban migrants with rural hukou (rural migrants), the second group is inter-city migrants with urban hukou from other

14. John Giles, Albert Park and Juwei Zhang, "What Is China's True Unemployment Rate?", China Economic Review, vol. 13, no. 4, 2005, pp. 430-443; John Knight and Jinjun Xue, "How High Is Urban Unemployment Rate in China?", Journal of Chinese Economic and Business Studies, vol. 4, no. 2, 2006, pp. 91-107; Dorothy J. Solinger, "Why We Cannot Count the 'Unemployed,'” The China Quarterly, vol. 167, 2001, pp. 671-688.

15. As a practice, the relative poverty line should be equivalent to $40-60$ percent of the median income. It should be noted that this statistic excludes urban residents without local hukou, or the floating population (liudong renkou) according to the official classification. See Ministry of Civil Affairs, 2009 Niandu quanguo minzheng shiye fazhan tongji baogao (Statistical Report for National Civil Affairs, 2009), Beijing, Ministry of Civil Affairs, 2010.

16. Some other sources report higher estimates depending on operational definitions.

17. There have been some breakthroughs recently. For example, in Chongqing Municipality, 10 million rural residents will be converted to urban hukou by 2020. See Guilin Zhang, "Chongqing qidong huji gaige: weilai shinian tuidong qianwan nongmin bian shimin" (Chongqing reforms Hukou: Transforming ten million farmers into urban citizens), retrieved on 28 July 2010 from http://www.gov.cn/jrzg/2010-07/28/content_1666121. htm.

18. Kam Wing Chan, "The Chinese Hukou System at 50," Eurasian Geography and Economics, vol. 50, no. 2, 2009, pp. 197-221; Kam Wing Chan and Li Zhang, "The Hukou System and Rural-Urban Migration in China: Processes and Changes," The China Quarterly, vol. 160, 1999, pp. 818-855; Fei Guo and Robyn Iredale, "The Impact of Hukou Status on Migrants' Employment: Findings from the 1997 Beijing Migrant Census," International Migration Review, vol. 38, no. 2, 2004, pp. 709-731; Zhongwei Zhao and Fei Guo (eds.), Transition and Challenge: China's Population at the Beginning of the 21st Century, Oxford, Oxford University Press, 2007.

19. Cf. the study by Fei Guo and Wenshu Gao, "What Determines the Welfare and Social Security Entitlements of Rural Migrants in Chinese Cities?" in Ingrid Nielsen and Russell Smyth (eds.), Migration and Social Protection in China, Singapore, World Scientific, 2008. Also see John Whalley and Shunming Zhang, "Inequality Change in China and (Hukou) Labour Mobility Restrictions," NBER Working Paper no. 10683, 2004; Kevin Honglin Zhang and Shunfeng Song, "Rural-Urban Migration and Urbanization in China: Evidence from Time-Series and Cross-Section Analyses," China Economic Review, vol. 14 , no. 4, 2003, pp. 386-400.

20. Cf. the following research: Asian Development Bank, Poverty Profile of the People's Republic of China, Manila, Asian Development Bank, 2004; Athar Hussain, Urban Poverty in China: Measurement, Patterns and Policies, Geneva, International Labour Office, 2003.

21. Yang Du, Robert Gregory, and Xin Meng, "The Impact of the Guest-Worker System on Poverty and the Well-Being of Migrant Workers in Urban China," in Ligang Song (ed.), The Turning Point in China's Economic Development, Canberra, Asia Pacific Press, 2006.

22. Albert Park and Dewen Wang, "Migration and Urban Poverty and Inequality in China," China Economic Journal, vol. 3, no. 1, 2010, pp. 49-67.

23. Recently, particular attention has been given to college graduates who move to or stay in large cities after graduation. See Si Lian (ed.), Yizu: Daxue biyesheng jujucun shilu (Ant tribe: A study of college graduate villages), Nanning, Guangxi shifan daxue chubanshe (Guangxi Normal University Press), 2009. Also refer to C. Cindy Fan, "The Elite, the Natives, and the Outsiders: Migration and Labor Market Segmentation in Urban China," Annals of the Association of American Geographers, vol. 92, no. 1, 2002, pp. 103-124. 
Table 2. Information on studied cities ${ }^{(1)}$

\begin{tabular}{l|c|c|c|c|c} 
& National & Beijing & Tianjin & Shanghai & Guangzhou \\
\hline Urban population (millions) & 606.67 & 14.39 & 9.08 & 12.17 & 7.84 \\
\hline GDP (billion yuan) & 30,067 & 1,048 & 635 & 1,370 & 822 \\
\hline GDP per capita (yuan) & 22,698 & 63,029 & 55,473 & 73,124 & 81,233 \\
\hline GDP growth rate (percentage/year) & 9.0 & 9.0 & 16.0 & 9.7 & 12.3 \\
\hline $\begin{array}{l}\text { Disposable income per capita } \\
\text { (yuan/year) }\end{array}$ & 15,780 & 24,725 & 19,423 & 26,675 & 25,317 \\
\hline Consumption per capita (yuanlyear) & 11,243 & 16,460 & 13,422 & 19,398 & 20,836 \\
\hline Mean wage (yuan/year) & 29,229 & 56,328 & 41,748 & 56,565 & 45,365 \\
\hline $\begin{array}{l}\text { Self-registered unemployment }{ }^{(2)} \\
\text { (percentage) }\end{array}$ & 4.2 & 1.8 & 3.6 & 4.2 & 2.3 \\
\hline MLSS poverty relief recipients ${ }^{(3)}$ & $23,347,864$ & 145,075 & 156,305 & 340,797 & 45,000 \\
\hline MLSS coverage (percentage) & 3.85 & 1.01 & 1.72 & 2.80 & 0.57 \\
\hline
\end{tabular}

Notes: 1. Statistics reported here are for local urban hukou only; 2. Chinese authorities do not report sampling unemployment rate. 3. MLSS is the abbreviation for the Minimum Living Standard Scheme.

Sources: Authors' calculation and statistics from China Statistical Yearbook 2009 (NBS, 2009), Urban Minimum Living Standard Scheme Report 2008 (MCA, 2009), Guangzhou Statistical Yearbook 2009 (GBS, 2009), Beijing Statistical Report 2008 (BBS, 2009), Shanghai Statistical Report 2008 (SBS, 2009) and Tianjin Statistical Report 2008 (TBS, 2009).

cities (urban migrants), and the last group is local residents with local urban hukou (urban locals). ${ }^{(24)}$ As indicated in the previous section, studies on China's internal migration tend to focus on rural-to-urban migrants, given that they make up the majority of the migrant population, they have been disadvantaged by public policies, and they have suffered institutional discrimination for more than five decades. However, the literature has taken very little note of inter-city or urbanto-urban migrants. By introducing urban-to-urban migrants, this study hopes to contribute to the understanding of the role of the household registration system (hukou) in determining people's well-being. By contrasting rural-to-urban migrants with urban-to-urban migrants, we hope to better understand how two types of hukou dichotomy (i.e. rural vs. urban hukou and local vs. non-local hukou) affect people's well-being.

Urban poverty and inequality and their interweaving with political, economic, and social factors form a complex topic, especially in transitional China. Rather than attempting an exhaustive examination of these issues, we aim to offer a laconic analysis on the most recent data available to depict a rapidly changing urban China and to extend our focus to some less developed research areas. The next section introduces the data and methodology we employed and provides some descriptive statistics. Before proceeding to the fourth section on the measurement of poverty and inequality, the third section examines the labour market performances of the three population groups in our study. The last section then presents some concluding remarks.

\section{Background, data and methodology}

This study was funded by an Australian Research Council Discovery project entitled Migrant Labour in Large Chinese Cities, through which the data was collected in 2008 in collaboration with local research institutions and universities in four Chinese megacities, including the municipalities of Beijing, Shanghai, and Tianjin, and Guangzhou, the capital of Guangdong Province. Beijing and Tianjin are neighbouring

24. A migrant is generally defined as a person working outside his or her place of hukou registration. In Chinese government statistics and documents, the Chinese term nongmin gong is used for rural-urban migrants. 
Table 3. Survey sample distribution in cities and by groups

\begin{tabular}{l|c|c|c|c} 
& Urban locals & Urban migrants & Rural migrants & Subtotal (\%) \\
Beijing & 112 & 151 & 197 & $460(26 \%)$ \\
\hline Tianjin & 59 & 62 & 375 & $496(27 \%)$ \\
\hline Shanghai & 70 & 48 & 281 & $399(22 \%)$ \\
\hline Guangzhou & 158 & 120 & 164 & $442(25 \%)$ \\
\hline Subtotal (\%) & $399(\mathbf{2 2} \%)$ & $\mathbf{3 8 1}(\mathbf{2 1} \%)$ & $\mathbf{1 , 0 1 7 ( 5 7 \% )}$ & $\mathbf{1 , 7 9 7 ( 1 0 0 \% )}$ \\
\hline \hline
\end{tabular}

Source: Authors' data and calculation.

cities located in Northern China; Shanghai is situated in the Yangtze River Delta on the east coast; Guangzhou is a coastal city in southern China's Pearl River Delta. These cities are long-standing economic powerhouses and political and economic centres in these three most developed regions of China. They represent the so-called China miracle of the last three decades, as evidenced by their rapid urbanisation incurred by massive population inflow, double-digit annual GDP growth, and so forth (see Table 2). For example, Guangdong's GDP recently overtook that of Saudi Arabia, Argentina, and South Africa and would rank sixteenth if classified as one of the G20 economies. The per capita GDP of all these cities has approached or already overtaken the lower-tier economies in the G20 league. ${ }^{(25)}$

A stratified random sampling method was used to collect representative data. In each city, one urban and one suburban district were randomly selected, and then two neighbourhoods (juweihui) were randomly picked from each district. One hundred randomly selected households in each selected neighbourhood were interviewed with the aid of questionnaires to collect both individual and household data. Information collected in the survey relevant to economic wellbeing and poverty includes household income, expenditure, and savings, as well as individual family members' employment status and income, welfare entitlements, social security benefits, etc. The survey collected 1,797 valid questionnaires comprising 399 urban locals, 381 urban-to-urban migrants, and 1,017 rural-to-urban migrants, which made up 22,21 , and 57 percent of the sample, respectively (see Table 3 for details). ${ }^{(26)}$

To estimate the poverty trends and to investigate how social and economic changes have impacted the urban subgroups, Foster-Greer-Thorbeck (FGT) measures were used to provide more decomposable information than a conventional headcount-only poverty index could do: ${ }^{(27)}$

$$
P_{\alpha}=\frac{1}{N} \sum_{i=1}^{N}\left(\frac{G_{i}}{z}\right)^{\alpha}
$$

where $i$ represents the $i$ th individual among $N$ individuals; $G_{i}$ is the poverty gap between the monetary poverty line $(z)$ and income per capita of the ith individual's household $\left(x_{i}\right)$, expressed as $G_{i}=z-x_{i}\left(\right.$ with $G_{i}=0$ when $\left.x_{i}>z\right) ; \alpha$ is an ethical parameter equal to or greater than zero. When $\alpha=0$, the equation stands for the poverty headcount ratio $\left(P_{0}\right.$, i.e. the fraction of the population below the poverty line); when $\alpha=1$, it represents the poverty gap $\left(P_{l}\right.$, i.e., the intensity of poverty) as the percentage of the poverty line, taking into account the total shortfall of individual income below a certain poverty standard; when $\alpha=2$, it estimates an index of the weighted poverty gap, namely poverty severity $\left(P_{2}\right)$. In this paper, we use FGT indices for measuring overall as well as subgroup poverty across cities and hukou status.

Three major types of poverty and income thresholds are used in this study. First, we use the official income threshold according to the Minimum Living Standard Scheme (MLSS, or dibao in Chinese), a monthly transfer program designed to provide relief to urban poor with local urban hukou. An eligible MLSS recipient receives a relief transfer payment equivalent to the gap between the household income per capita as estimated by governmental agency (e.g. neighbourhood committee) and the local MLSS benefit poverty line. In 2008, the national mean MLSS benefit line was 205 yuan per month and the MLSS lines in these cities

25. Jianping Li, Minrong Li, and Yanjing Gao (eds.), Zhongguo shengyu jingji zonghe jingzhengli fazhan baogao, 2008-2009 (Annual report on overall competitiveness of China's provincial economies, 2008-2009), Beijing, Social Sciences Academic Press, 2010.

26. The survey asked interviewees directly about the types of their hukou.

27. James Foster, Joel Greer, and Erik Thorbecke, "A Class of Decomposable Poverty Measures," Econometrica, vol. 52, no. 3, 1984, pp. 761-766. 
were 330 yuan for Beijing, Tianjin, and Guangzhou and 350 yuan for Shanghai. A higher MLSS line of 350 yuan per month is applied in this study for simplicity and because the MLSS standards have been considered too low in these cities. The bottom two rows in Table 2 show that the overall coverage of MLSS in China was 3.85 percent while the coverage of MLSS in our sample cities was extremely low (ranging between 0.57 and 2.8 percent), although these cities had the highest MLSS lines compared with other regions and cities. It means that the official relief program could only provide very limited help to a small proportion of poor who were under the specified benefit poverty lines in the studied cities. This is not to deny the effort the Chinese government has made to improve the MLSS in terms of poverty lines and poverty targeting, although some scholars have criticised the program as a passive response to the social externalities of market reform. ${ }^{(28)}$ As of June 2010, among these four cities, Shanghai has the highest MLSS line (450 yuan), followed by Tianjin (430 yuan), Beijing, and Guangzhou (both 410 yuan). ${ }^{(29)}$ In other words, the poverty standard has increased by approximately one fifth in absolute terms since the year of our survey. The MLSS lines in these cities are also among the highest nationally. Since local urban hukou are essential for eligibility, urban-to-urban and rural-to-urban migrants are excluded as beneficiaries of the program. We therefore apply the same standards to these two institutionally excluded groups, as they are equally disadvantaged in urban MLSS program.

Second, we used two other poverty lines based on the World Bank's $\$ 1 /$ day poverty standard (or more precisely $\$ 1.25 /$ day after several revisions since its introduction), which has been widely used to evaluate and compare poverty internationally. The $\$ 1.25 /$ day line is approximately equivalent to 150 yuan per month in PPP terms in 2008. Considering that the standard of living in these cities is among the highest in China, this poverty line is obviously inappropriate in our study setting, not to mention that it is even lower than the MLSS line. As an amendment, we followed the example of some other studies by setting two higher lines, one 2.5 times higher than the $\$ 1.25 /$ day standard and the other three times higher. Their monthly poverty lines (hereafter $\mathrm{WB}_{1}$ and $\mathrm{WB}_{2}$ ) in Chinese currency are 450 and 600 yuan respectively, the latter of which is about 42 percent of the urban mean income.

In the absence of national median income per capita - a more meaningful reference to test income distribution national income per capita is used as the third income threshold. According to official statistics, the monthly in- come per capita for a migrant working in the eastern region was 1,422 yuan in 2009 , which is at the same level as the national monthly income per capita in 2008. Therefore the third income threshold we imported to the FGT approach was national monthly income per capita (i.e. 1,422 yuan/month) as a reference for the other two types of poverty lines for the purpose of revealing income distribution at a higher standard within our samples. Relying on these poverty and income thresholds, the disposable features of FGT indices allow us to measure and compare poverty and income level in different groups and to examine how poverty changes in response to the increase of poverty lines. ${ }^{(30)}$

We also examined inequality through two traditional and revealing approaches. The Gini is a synthetic index that compresses all information about inequality into a value between zero and one. The Gini coefficient is calculated as:

$$
\text { Gini }=1-\frac{1}{N} \sum_{i=1}^{n}\left(y_{i}+y_{i-1}\right)
$$

where $y$ is income. A result of zero expresses perfect equality and a value of one expresses maximal inequality in income distribution. We then used the Gini coefficient to plot a Lorenz curve to visually represent income inequality. The further the Lorenz curve lies below the 45-degree line representing perfect equality, the more unequal is the distribution of income.

\section{Labour market disparities}

Although competition between migrants and locals has been observed, research indicates increasing segmentation of the labour market. ${ }^{(31)}$ In light of these views, this section examines some important aspects of the labour market in the selected cities. It was found that urban locals still have strong advantages in terms of job searching channels compared to

28. Dorothy J. Solinger, "The Dibao Recipients: Mollified Anti-Emblem of Urban Modernization," China Perspectives, no. 4, 2008, pp. 36-46.

29. Ministry of Civil Affairs, "Minimum Living Standards in 36 Central Cities as of June 2010," 2010, retrieved on 8 August 2010 from http://www.dibao.org/content. aspx?lid=1820\&type=tj02.

30. Nowadays poverty is recognised as a multidimensional phenomenon; therefore the poverty line alone cannot fully reveal poverty as a complex multifaceted occurrence. This paper adopts poverty lines neither for the purposes of defining nor of counting the poor as a standard, but to compare the poverty indices under different income poverty thresholds and to collate the sensitivity of these thresholds. Although income poverty alone may not be an exhaustive indicator of living conditions, as low-income households may spend either less or more than they earn, it still has important implications in making and implementing policies as a more convenient and straightforward approach than others. 
Table 4. Distribution of job searching channels by three groups

\begin{tabular}{l|c|c|c|c|c|c}
\multirow{2}{*}{$\begin{array}{l}\text { Job searching } \\
\text { Government assignment }\end{array}$} & \multicolumn{2}{c}{ Urban locals } & \multicolumn{2}{c}{ Urban migrants } & \multicolumn{2}{c}{ Rural migrants } \\
Cases & Percent & Cases & Percent & Cases & Percent \\
\hline Private employment agency & 82 & 20.9 & 4 & 1.1 & 13 & 1.3 \\
\hline Government employment agency & 6 & 1.5 & 16 & 4.3 & 51 & 5.1 \\
\hline Friend/relative's recommendation & 19 & 4.8 & 11 & 2.9 & 18 & 1.8 \\
\hline Job searching on one's own & 84 & 21.6 & 102 & 27.3 & 417 & 41.4 \\
\hline Response to job advertisement & 60 & 15.3 & 96 & 25.7 & 302 & 30.0 \\
\hline Employer's job fair/recruitment & 23 & 5.9 & 46 & 12.3 & 33 & 3.3 \\
\hline Other & 93 & 23.7 & 64 & 17.1 & 92 & 9.1 \\
\hline & 25 & 6.4 & 35 & 9.4 & 81 & 8.0 \\
\hline
\end{tabular}

Source: Authors' data and calculation.

the other two groups (see Table 4). One-fifth of urban locals were assigned to jobs by their local governments and nearly one-fourth got jobs from employer recruitment fairs, while only 15 percent needed to search for jobs on their own. A large proportion of rural migrants, however, went to their destination cities relying either totally on their own abilities or on existing social networks (often kinship or friendship) for job recommendation and information on recruitment opportunities. Compared with urban hukou holders, rural migrants' job searches fell back on two main channels: asking help from their friends and relatives via their constrained social networks in cities (4l percent) and looking for jobs on their own (30 percent). A very small proportion of rural migrants got jobs through employer job fairs or direct recruitment. Compared to rural migrants, migrants from other cities (urban migrants) have more diversified job searching methods: a smaller proportion of urban migrants got their jobs through friends or relatives and a higher proportion (than rural migrants) did so through response to job openings and employers' direct recruitment.

The different ways of obtaining jobs by these three distinct population groups in China's large cities clearly suggest that the legacy of China's long-term institutional mechanism, the hukou, is still effective in determining access to public support and social capital in the job market. It seems clear that government assistance in job searches is mainly available to those who are able to transfer their hukou to the city of destination. Those who are not locally registered but come from other urban areas are more likely to be hired through recruitment fairs or by responding to recruitment advertisements, as they are more likely to be better educated and tend to be more competitive. It is perhaps not unexpected that the majority of rural migrants have to rely on their own abilities or personal relationships to land a job in these large cities. It by no means suggests, however, that rural migrants are more competitive in the job market in these large cities. Rather, it may imply the informal nature of the jobs they are more likely to land. The analysis in the next section on the type of employment might offer some further explanation.

On the one hand, there is no unanimous academic and official agreement on the definitions for the informal sector and informal employment in China. The Chinese government, on the other hand, has been encouraging the development of the informal sector and informal employment that is typified by less supervised small business activities and a largely unstable short-term or uncontracted labour relationship. It is estimated that the number of informal employees has reached 136 million and that they contribute 35 percent of GDP. ${ }^{(32)}$ For the sake of simplicity, this paper defines the informal sector as a concept relative to the more regulated and supervised sector in the socialist market economy. In this sense, governmental departments and related institutions (e.g. schools, public transport companies, etc.), post-reform state- and collective-owned, foreign-funded, and joint-venture enterprises are more likely to provide employees with formal

31. See John Knight and Lina Song, Towards a Labour Market in China, Oxford, Oxford University Press, 2005; John Knight and Linda Yueh, "Job Mobility of Residents and Migrants in Urban China," Journal of Comparative Economics, vol. 32, no. 4, 2004, pp. 637660; John Knight and Linda Yueh, "Segmentation or Competition in China's Urban Labour Market?", Cambridge Journal of Economics, vol. 33, no. 1, 2009, pp. 79-94.

32. Yun Ren and Xizhe Peng (eds.), 2006 Nian Zhongguo feizhenggui jiuye fazhan baogao (Report on China's Informal Employment, 2006), Chongqing, Chongqing Press, 2007. 
Table 5. Distribution of types of employers by three groups

\begin{tabular}{|c|c|c|c|c|c|c|}
\hline \multirow{2}{*}{ Types of employers } & \multicolumn{2}{|c|}{ Urban locals } & \multicolumn{2}{|c|}{ Urban migrants } & \multicolumn{2}{|c|}{ Rural migrants } \\
\hline & Cases & Percent & Cases & Percent & Cases & Percent \\
\hline Government and related institutions ${ }^{(1)}$ & 126 & 32.1 & 32 & 8.6 & 48 & 4.8 \\
\hline State-owned enterprise & 72 & 18.4 & 29 & 7.8 & 53 & 5.3 \\
\hline Collective-owned enterprise & 33 & 8.4 & 20 & 5.3 & 42 & 4.2 \\
\hline Foreign-funded enterprise & 25 & 6.4 & 37 & 9.9 & 84 & 8.3 \\
\hline Joint venture enterprise & 64 & 16.3 & 126 & 33.7 & 289 & 28.7 \\
\hline Private business & 17 & 4.3 & 56 & 15.0 & 233 & 23.1 \\
\hline Small private business (getihu) ${ }^{(2)}$ & 33 & 8.4 & 58 & 15.5 & 203 & 20.1 \\
\hline Self-employed & 22 & 5.6 & 16 & 4.3 & 56 & 5.6 \\
\hline Total & 392 & 100 & 374 & 100 & 1008 & 100 \\
\hline
\end{tabular}

Source: Authors' data and calculation.

Notes: 1. This category includes public service institutions (shiye danwei), educational institutions (da, zhong, xiao xue) and research institutions (yanjiu danwei); 2. Getihu is a small private business of which the ownership is limited to members of a family and which can employ a small number of non-family employees.

and legitimate contracts and benefits (e.g., employer contributions to pensions and to medical and unemployment insurance) than are small-scale joint-ventures and private enterprises and small private businesses (getihu). Table 5 presents the types of employers the sampled respondents worked for. Compared with the other two groups, rural migrants were more concentrated in the informal sector, whilst urban locals were more concentrated in the formal sector. Among rural migrants, 23 percent worked in private enterprises, 20 percent in getihu, and 6 percent were self-employed. The situation of urban migrants is somewhere between that of urban locals and rural migrants. A significantly larger proportion of urban locals than other groups worked in government and related institutions ( 32 percent), state-owned enterprises (18 percent), and collective-owned enterprises (8 percent), and a lower proportion in joint-ventures, private enterprises, and small private businesses. Urban migrants also tended to be concentrated in the informal sector, although at a lower proportion than rural migrants. Further analysis finds significant disparities also exist in terms of the major types of businesses the different groups worked for. Approximately 53 percent of rural migrants worked for employers in the areas of sales, catering, logistics, marketing, storage, and manufacturing, and a very small proportion of them were employed in the areas of education, entertainment, arts, technical services, finance, banking, and so on - urban migrants had advantages over rural migrants in these areas thanks to generally better social capital. Not surprisingly, 32 percent of urban locals worked in government departments, as 21 per- cent were assigned jobs by the local government, while less than 2 percent of migrants held such positions. Although the survey did not directly collect unemployment data following the first job, job security is obviously less an issue for locals than for both types of migrants, as revealed by the former's lower unemployment rate and shorter unemployment (if any) overall in the last year.

Table 6 shows the percentage distribution of the size of enterprise/organisation in which respondents were employed. Nearly half of rural migrants were employed by small employers with fewer than 10 employees, and a quarter of them worked for employers with 11 to 50 staff. ${ }^{(3)}$ In terms of the types and length of labour contracts (if any) and the occupations among our samples, we found that more than threefourths of urban locals and nearly 58 percent of urban migrants had signed contracts with their employers (see Table 7). However, 63 percent of rural migrants had not signed any form of contract. In terms of fixed term contracts, a higher proportion of urban locals had signed relatively longperiod fixed-term contracts of two to five or over five years. One-fifth of urban locals had signed continuing contracts, while only 6.5 to 8.4 percent of migrants had obtained such contracts. Although a small number of migrants worked in governmental institutions (refer to Table 5), most of them were under short-term contracts and worked as cleaners, typists, gardeners, security guards, and so on. For rural mi-

33. Some researchers suggest that working in a business with fewer than 30 staff may be regarded as informal employment in China. 
Table 6. Distribution of size of employers by three groups

\begin{tabular}{|c|c|c|c|c|c|c|}
\hline \multirow{2}{*}{ Number of employees } & \multicolumn{2}{|c|}{ Urban locals } & \multicolumn{2}{|c|}{ Urban migrants } & \multicolumn{2}{|c|}{ Rural migrants } \\
\hline & Cases & Percent & Cases & Percent & Cases & Percent \\
\hline Up to 10 & 71 & 18.3 & 123 & 33.2 & 464 & 46.9 \\
\hline $11-50$ & 114 & 29.3 & 86 & 23.2 & 234 & 23.7 \\
\hline $51-300$ & 108 & 27.8 & 87 & 23.5 & 159 & 16.1 \\
\hline $301-1,000$ & 49 & 12.6 & 48 & 13.0 & 82 & 8.3 \\
\hline Above 1,000 & 47 & 12.1 & 26 & 7.0 & 50 & 5.1 \\
\hline Total & 389 & 100 & 370 & 100 & 989 & 100 \\
\hline
\end{tabular}

Source: Authors' data and calculation.

Table 7. Distribution of types and lengths of contract signed by three groups

\begin{tabular}{|c|c|c|c|c|c|c|}
\hline & \multicolumn{2}{|c|}{ Urban locals } & \multicolumn{2}{|c|}{ Urban migrants } & \multicolumn{2}{|c|}{ Rural migrants } \\
\hline & Cases & Percent & Cases & Percent & Cases & Percent \\
\hline With contract & 303 & 77.9 & 214 & 57.7 & 367 & 37.1 \\
\hline Without contract & 86 & 22.1 & 157 & 42.3 & 621 & 62.9 \\
\hline Total & 389 & 100 & 371 & 100 & 988 & 100 \\
\hline \multicolumn{7}{|l|}{ With contract } \\
\hline Continuing contract & 66 & 21.8 & 14 & 6.5 & 31 & 8.4 \\
\hline Fixed-term contract & 237 & 78.2 & 200 & 93.5 & 336 & 91.6 \\
\hline Total & 303 & 100 & 214 & 100 & 367 & 100 \\
\hline \multicolumn{7}{|l|}{ Fixed-term contract } \\
\hline Up to 0.5 year & 15 & 6.3 & 13 & 6.5 & 38 & 11.3 \\
\hline $0.5-1$ year & 106 & 44.7 & 111 & 55.5 & 213 & 63.4 \\
\hline $2-5$ years & 94 & 39.7 & 62 & 31.0 & 77 & 22.9 \\
\hline More than 5 years & 22 & 9.3 & 14 & 7.0 & 8 & 2.4 \\
\hline Total & 237 & 100 & 200 & 100 & 336 & 100 \\
\hline
\end{tabular}

Source: Authors' data and calculation.

grants, common occupations were service staff - e.g. restaurant waiter/waitress - (42 percent), cleaners and salespersons, and industrial workers (23 percent); for urban migrants, the main jobs were service staff ( 41 percent), technician (23 percent), and office clerk ( 13 percent); for urban locals, the main jobs were official clerk (23 percent), service staff (21 percent), and technician (14 percent).

In sum, urban locals, urban migrants, and rural migrants present different labour market patterns in terms of their approaches to the job market, their employment sectors, and the scale of their employers. The next section extends the examination to income poverty and inequality, which are among the most direct outcomes of these different patterns in the emerging labour market in China.

\section{Urban poverty and inequality}

The standard of living in China has been improved steadily over the past three decades or so. Official statistics show that the Engel's coefficients - a percentage measure of the amount of food expenditure relative to the amount of income - of urban and rural households decreased in similar downward trends from 58 to 37 percent and from 67 to 43 percent, respectively, between 1978 and 2008 (Figure 1). During the same period, income increases in percentage terms were dramatic, as both urban and rural annual incomes per capita expanded almost nine times between 1978 and 2008 (Figure 2). Meanwhile, the rural-urban income gap has been growing since 1997 after some improve- 
Figure 1. Engel's coefficients of urban and rural households (percent)

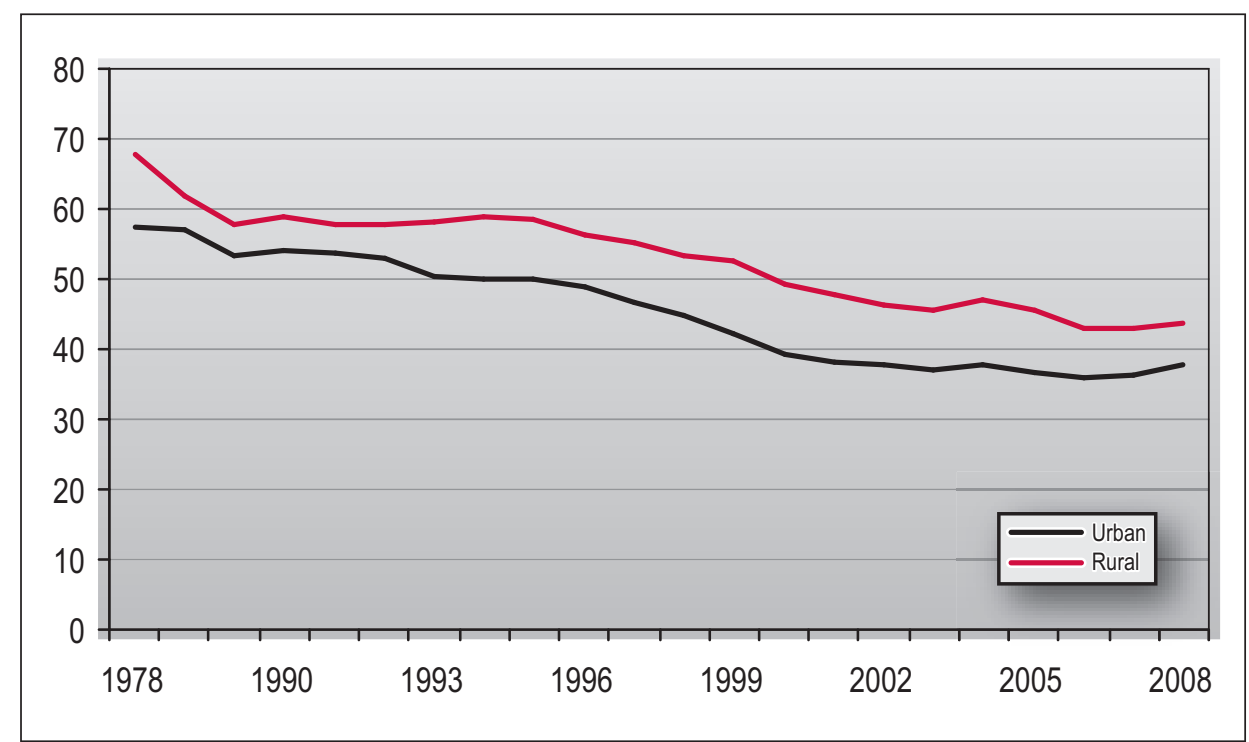

Source: China Statistical Yearbook (NBS, 2009).

Figure 2. Relative index of annual income per capita in urban and rural area

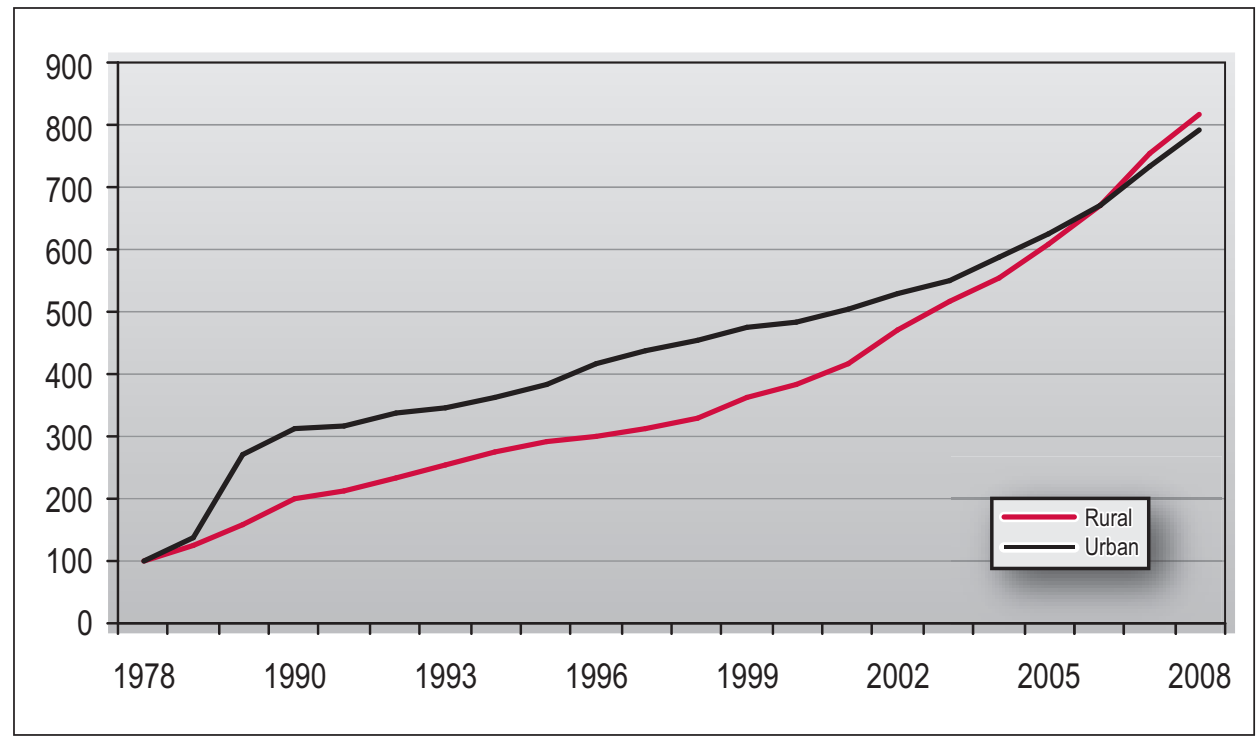

Source: China Statistical Yearbook (NBS, 2009); Note: 1978 as the base year and as 100.

ments in narrowing their gap in the 1980s and early 1990s, reflecting the shift of economic policy priorities from the rural to urban areas and from agricultural to export-oriented economies in the last three decades (Figure 3). Actually, research has found that China's rural-urban income gap is much larger than in most other developing economies, ${ }^{(34)}$
34. Robert Eastwood and Michael Lipton, "Rural and Urban Income Inequality and Poverty: Does Convergence between Sectors Offset Divergence within Them?", in Giaovanni Andrea Cornia (ed.), Inequality, Growth, and Poverty in an Era of Liberalization and Globalization, Oxford, Oxford University Press, 2004; John Knight, Shi Li, and Lina Song, "The Rural-Urban Divide and the Evolution of Political Economy in China," in James Boyce, Stephen Cullenberg, and Prasanta Pattanaik (eds.), Human Development in the Era of Globalization: Essays in Honor of Keith B. Griffin, Northampton, Edward Elgar, 2006; Albert Park, "Rural-Urban Inequality in China," in Shahid Yusuf and Tony Saich (eds.), China Urbanizes: Consequences, Strategies, and Policies, Washington, The World Bank, 2008. 
Figure 3. Ratio of rural to urban annual income per capita, 1978-2008

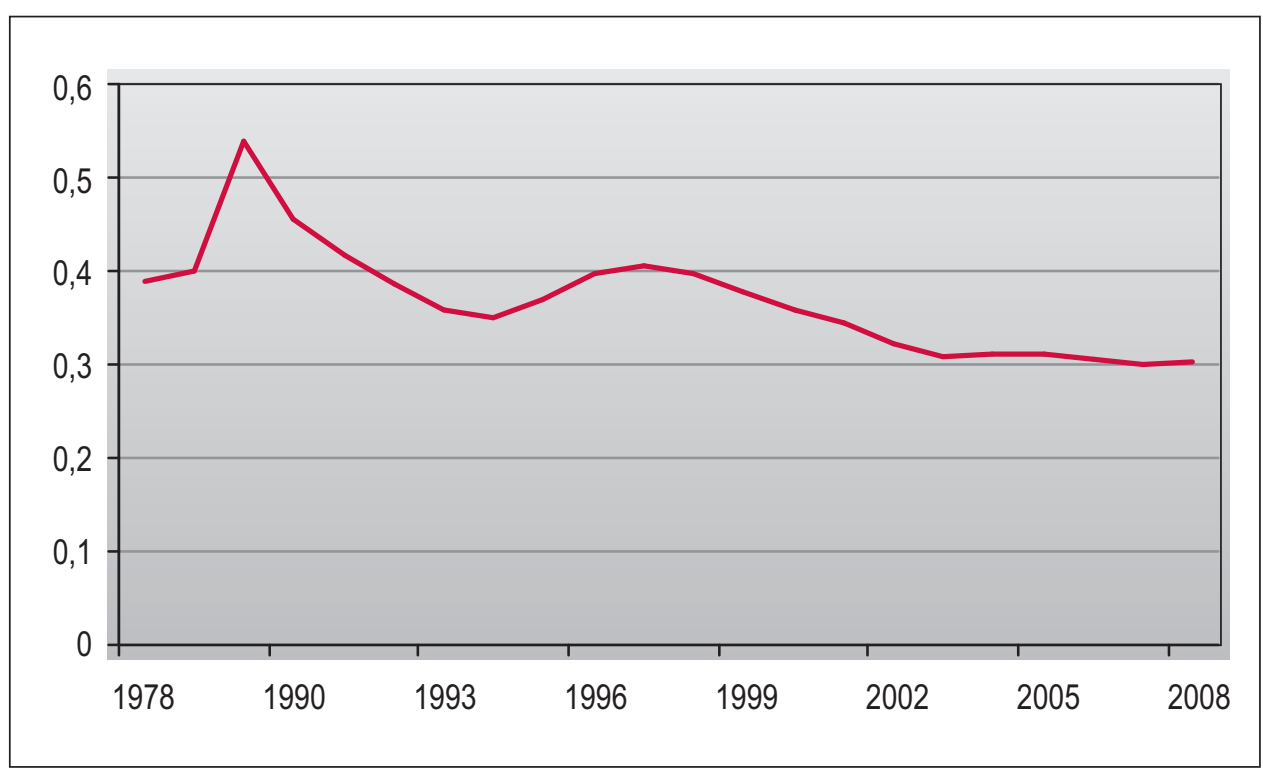

Source: China Statistical Yearbook (NBS, 2009).

and it has often been underestimated. As pointed out in the National Human Development Report for China, "If public housing subsidies, private housing imputed rent, pension, free medical care, and educational subsidises were included,... [it would bring] the urban-rural income ratio to about four-fold instead of the 3.2-fold acknowledged by official figures." ${ }^{(35)}$ Such rural-urban differences not only contribute to overall social inequality but also create strong incentives for internal migration through rising living costs and the prevalence of consumerism, although discriminatory measures persist against migrants, who are still often relegated to second-class status. ${ }^{(36)}$

Decomposing poverty, Table 8 presents overall and grouped poverty measures of the sampled population by using the MLSS line, two revised World Bank lines ( $\mathrm{WB}_{1}$ and $\mathrm{WB}_{2}$ ), and the urban monthly income per capita as explained in the methodology section. It gives an idea of the level of poverty in these cities and among the three groups according to various standards of measurement. Using the MLSS line, the overall poverty rate among our sampled population in all four cities was 6.2 percent, with poverty gap and severity indices of 2.3 and 1.5 percent. Between the MLSS and WB lines, poverty indices increased significantly. For instance, increasing the $\mathrm{WB}_{1}$ by one third to $\mathrm{WB}_{2}$ increased the poverty rate by 7.8 percent - a nearly 80 percent change. More than half of the sample did not reach the mean income, with a significant poverty gap and severity. Our sample population in Tianjin had the highest poverty rates under all standards, followed by Guangzhou, Beijing, and Shanghai. However, the other two poverty indices provided more complex information. For instance, using the MLSS line, Guangzhou's poverty gap and severity were the highest among the four cities. Shanghai performed the best in all poverty indices under all standards. In particular, its overall poverty rates were only around one percent under both the MLSS and WB। lines, significantly better than other cities in terms of extreme poverty rates.

The table also presents poverty indices according to hukou status. In the four cities, poverty indices among rural migrants were much higher than in the other groups, no matter which poverty line was applied. It is clear that the higher the standard of poverty line, the larger the difference in poverty indices between rural migrants and the other two groups. Not surprisingly, rural migrants contributed more to urban poverty than the other two groups. It is very interesting to note, however, that the differences in the poverty rate, gap, and severity indices between urban locals and urban migrants were not significant (mostly 0.1 to 0.3 percent), indicating that local hukou status may not be an overwhelmingly important factor

35. United Nations Development Programme, The National Human Development Report for China, New York, United Nations Development Programme, 2005, p. 27.

36. On the eve of the 2010 National People's Congress, 13 newspapers published an editorial calling for the abolition to the hukou system. The Chinese authorities quickly suppressed the editorial, and some editors lost their jobs. 
Table 8. Poverty indices by cities and hukou status

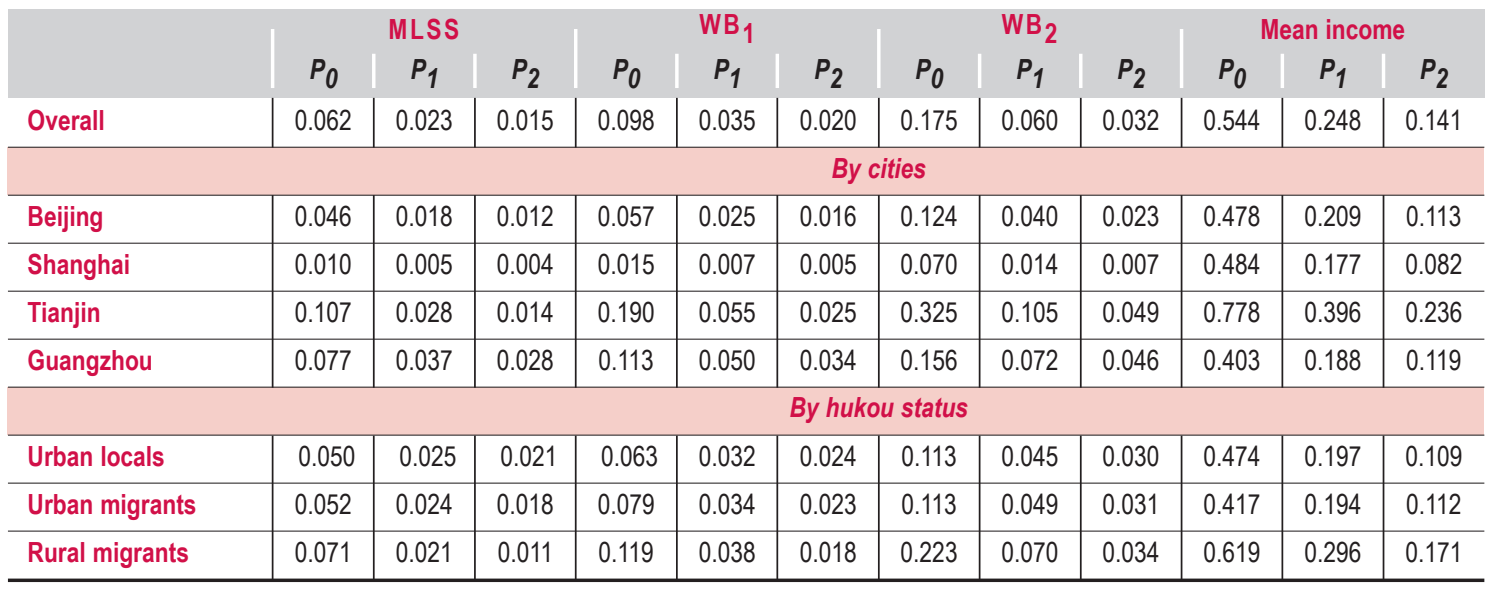

Notes: 1. Authors' calculation. 2. In 2008, the mean income in urban China was 17,067 yuan per year, or 1,422 yuan per month (NBS, 20002009). Chinese authorities do not report median income. It is reasonable to assume that poverty indices will shoot up if measured by the internationally prevailing poverty standard of $40-60 \%$ of median income.

$P_{0}-$ Poverty rate indices, $P_{1}-$ Poverty gap indices, $P_{2}-$ Poverty severity indices.

in predicting poverty among these two groups of samples. ${ }^{(37)}$ Migrants from other urban areas also performed about as well as locals in terms of income. It is the nature of the hukou, being a rural hukou or urban hukou holder, that makes a difference in the economic wellbeing of the group as a whole. This finding makes an interesting contrast with some recent studies on wage and employment entitlements and benefits among China's migrants, which were based on data collected in five Chinese cities. ${ }^{(38)}$ The multivariate analyses at the individual level in these studies indicate that the major disparity between local workers and migrant workers is not the wage difference, but rather that access to welfare and social security benefits and employment-related entitlements contribute to the widening gap between local workers and migrant workers. At the individual level, being a local worker does not necessarily enable one to earn a higher wage; the higher income earned by local workers resulted from access to professional and other more prestigious jobs. The two recent studies also found that hukou status was not significant in explaining wage gaps; educational attainment seems to play a greater role in one's level of income. The findings from the present paper, however, suggest that rural migrants as a group suffer more severe poverty compared with locals and migrants from other urban areas. This seemingly contradictory finding may suggest that even though at the individual level, all other factors being equal, rural migrants can attain income more or less equal to that of their local or urban migrant counterparts, they are still the most disadvantaged group in large Chinese cities in terms of monetary poverty. This is precisely because the lack of competitive human capital among rural migrants, such as educational attainment and vocational training, contributes to their lack of competitiveness in the labour market, causing them to suffer greater poverty. As indicated above, rural migrants were the main group of urban poor in large Chinese cities. The existing poverty relief program aimed at providing a minimum living allowance to locally registered urban poor has only been able to cover a very small proportion of the impoverished urban population, as stated in the background section.

Along with the emergence of urban poverty, disparities between urban and rural areas and within urban areas have increased dramatically. Nationally, China's income Gini coefficient has grown from 0.3 in 1978 to 0.45 in 2002; in particular, China reports the highest consumption Gini coefficient

37. Given the sample size and unavailability of statistics relating to the migrant population at the city level, we could not safely conclude that the difference of poverty indices between urban locals and urban migrants was comparatively insignificant at the population level. Nonetheless, as the survey followed a strictly representative sampling, the results are meaningful.

38. Survey data in these studies were collected in five Chinese cities (Beijing, Shijiazhuang, Shenyang, Wuxi, and Dongguan) between 2003 and 2005 through a project supported by the Ford Foundation. See the following two papers for details: Fei Guo and Wenshu Gao, "The Legacy of Socialist Dualism: Rural Migrants' Employment Status and Social Security Entitlements in Chinese Cities," The Proceeding of International Workshop of Migration and Social Protection in China, Beijing, 2007; Fei Guo and Wenshu Gao, "What Determines the Welfare and Social Security Entitlements of Rural Migrants in Chinese Cities?", op cit. 
Figure 4. Gini coefficients by hukou status

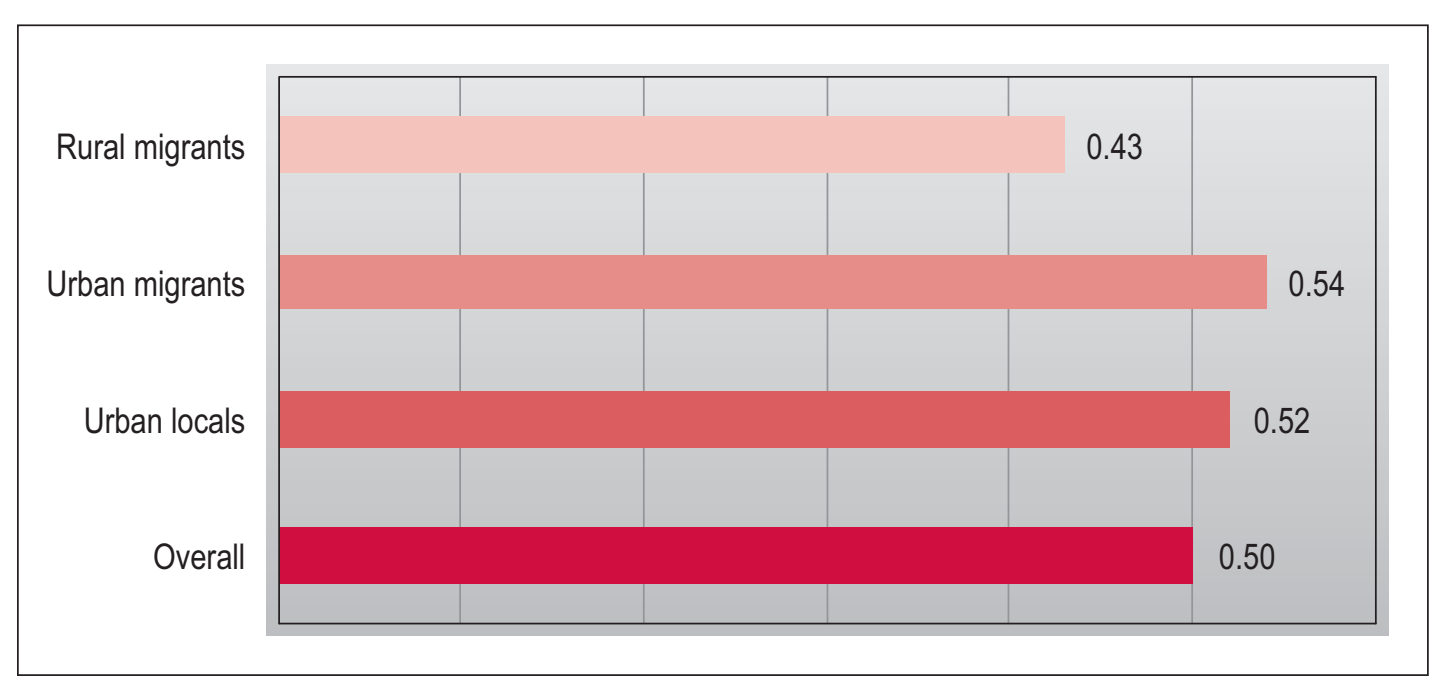

Source: Authors' data and calculation.

in Asia. ${ }^{(39)}$ In one of the few earlier studies of inequality among rural-urban migrants, larger nationwide inequality was found among migrant households than between rural and urban households in 2002. ${ }^{(40)}$ There has been criticism that some estimations report Gini coefficients that are significantly lower than people's perceptions; for example, a report estimates the coefficients as 0.22 in Beijing in 2002 and 0.32 in Shanghai between 2004 and 2005. These figures indicate good overall equality, and they were among the lowest of the world's largest cities in the early and mid 2000s. ${ }^{(41)}$ In fact, there have been many debates on Gini coefficient estimation methods and results. The Organisation for Economic $\mathrm{Co}_{0}$ Operation and Development recently suggested a slightly decreased Gini index from 0.41 in 2005 to 0.408 in 2007. ${ }^{(42)}$ However, some believe that China's Gini index, which has been steadily rising after exceeding the national warning level of 0.4 a decade ago, is now higher than 0.5. ${ }^{(43)}$

To test whether these assumptions and estimations are applicable to our samples, we examine in this section overall and grouped distribution of income by utilising the Gini coefficient and Lorenz curve, both of which are measures of social inequality in terms of monetary standards. Figure 4 presents Gini coefficients by hukou status. The overall Gini coefficient of four cities and all three groups is 0.50. Urban migrants have the highest Gini coefficient (0.54), reflecting the population diversity in this group. As shown in Table 5, a large proportion of urban migrants worked in the formal sector, including foreign and joint-venture enterprises, as well as in the public sector. Migrants from other urban areas would normally also include highly-educated college graduates who for some reasons are unable to transfer their hukou registration to the places of their current residence. Nonetheless, urban migrants would also include those who come to large cities to engage in low-skilled jobs if their places of origin could not provide opportunities for them. ${ }^{(44)}$ This diversity within the urban migrant group contributes to the greater Gini coefficient, therefore greater inequality, among this group. Urban locals have more or less the same level of inequality as urban migrants, as indicated by a Gini coefficient of 0.52 . This value is even higher than the overall national Gini coefficient in 2002, which takes into consideration rural/urban inequality. The high Gini coefficient

39. Tann vom Hove, "China's Urban Transition Causes Growing Inequality," 2008, retrieved on 1 July 2010 from http://www.citymayors.com/habitat/habitat08-china.html.

40. Azizur Rahman Khan and Carl Riskin, "Growth and Distribution of Household Income in China between 1995 and 2002," in Björn A. Gustafsson, Shi Li, and Terry Sicular (eds.) Inequality and Public Policy in China, Cambridge, Cambridge University Press, 2008.

41. United Nations-Habitat, State of the World's Cities, 2008/2009, Nairobi, United Nations Human Settlements Programme, 2008. This report uses official statistics to reach its conclusion on the case of Chinese cities.

42. Organisation for Economic Co-Operation and Development, Economic Survey of China 2010, Paris, OECD Headquarter, 2010.

43. Yaping Cong and Changjiu Li, Shouru fenpei shiheng dailai jingji shehui fengxian (Four aspects of income distribution inequality raise socio-economic risks), Beijing, Jingji cankao (Economic Information), 21 May 2010.

44. This is particularly the case in large cities. See, among others, C. Cindy Fan, "Economic Opportunities and Internal Migration: A Case Study of Guangdong Province, China," The Professional Geographer, vol. 48, no. 1, 2006, pp. 28-45; Si-Ming Li and Yat-Ming Siu, "A Comparative Study of Permanent and Temporary Migration in China: the Case of Dongguan and Meizhou, Guangdong Province," International Journal of Population Geography, vol. 3, no. 1 , 1997, pp. 63-82; Alice Goldstein and Shenyang Guo, "Temporary Migration in Shanghai and Beijing," Studies in Comparative International Development, vol. 27, no. 2, 1992, pp. 39-56. 
Figure 5. Lorenz curves by hukou status

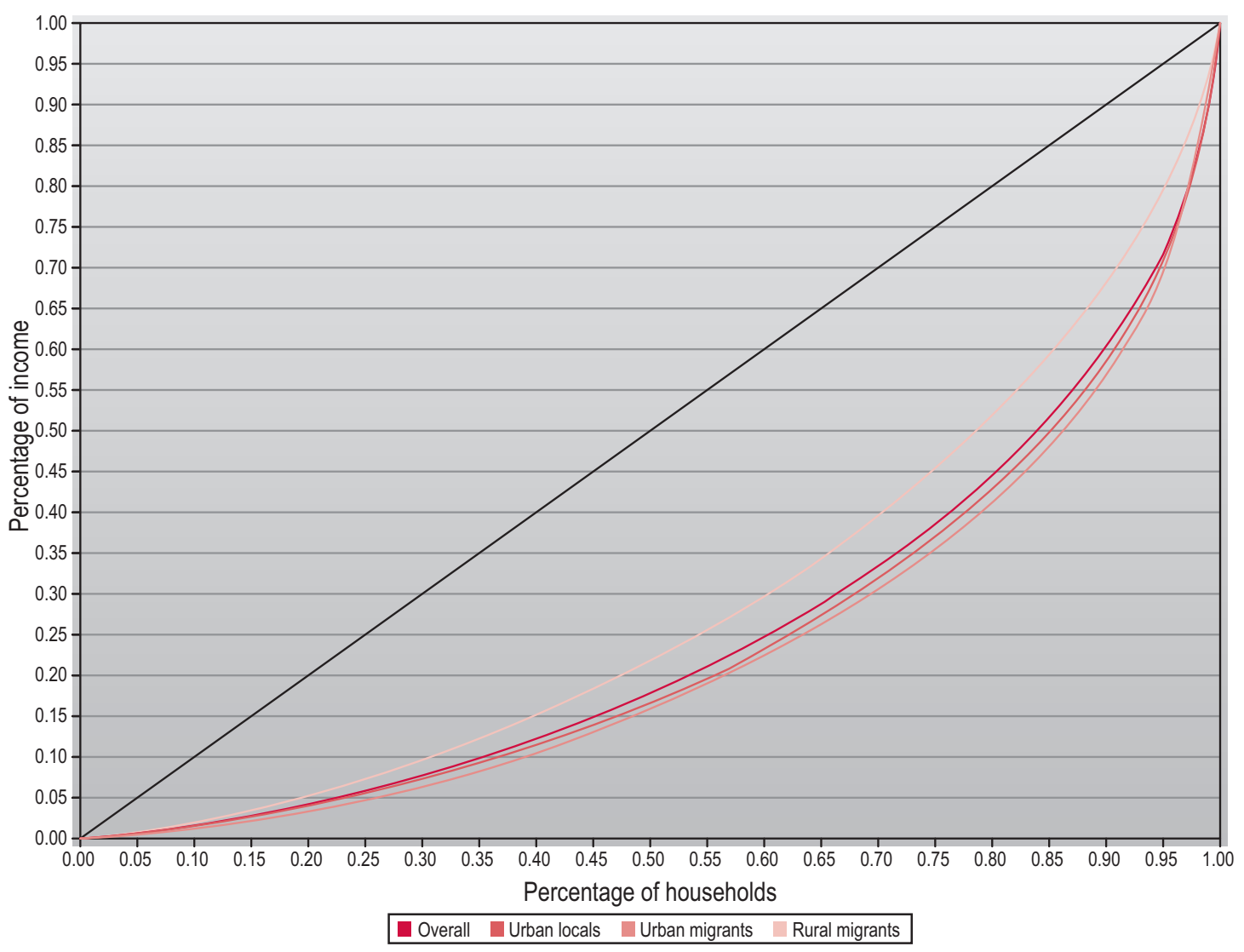

Source: Authors' data and calculation.

among urban locals in our studied cities offers a different angle for examining inequality in China. It seems that economic inequality exists not only between the rural and urban areas, but also within China's large cities and among urban locals. Among the three groups, rural migrants have the lowest Gini coefficient (0.43), meaning lower inequality within the group. This is an interesting but not surprising finding. Rural migrants as a group are perhaps more homogenous than urban migrants and urban locals. The common characteristics of rural migrants have been well documented in a number of previous studies. ${ }^{(4)}$ Some common characteristics of rural migrants include young, junior/high school educated, and engaging in low-skilled or semi-skilled jobs in cities. One key common feature also includes the likelihood that they will be treated as second-class citizens in Chinese cities. The relatively low Gini coefficient among rural migrants indicates relatively low inequality, but this does not necessarily imply a positive result. Taking the results of poverty rates and poverty gaps into consideration (see Table 8), one can only conclude that the relatively low Gini coefficient implies that rural migrants as a group are relatively equal at the bottom of the income spectrum.

These findings can be further illustrated by drawing Lorenz curves for visualising inequality among the three hukou groups (see Figures 5). The more the curve bends away from the 45-degree perfect equity line, the higher the inequality. If we divide the samples according to their hukou

45. Cf. Kenneth Roberts, "The Changing Profile of Labour Migration," in Zhongwei Zhao and Fei Guo (eds.), Transition and Challenge: China's Population at the Beginning of the 21st Century, Oxford, Oxford University Press, 2007; Fei Guo and Robyn Iredale, "The Impact of Hukou Status on Migrants' Employment: Findings from the 1997 Beijing Migrant Census," International Migration Review, vol. 38, no. 2, 2004, pp. 709-731; Feng Wang, "Gendered Migration and the Migration of Genders in Contemporary China," in Gail E. Henderson and Barbara Entwisle (eds.), Re-Drawing Boundaries: Work, Households, and Gender in China, Berkeley, University of California Press, 2000; Feng Wang and Anan Shen, "Double Jeopardy? Female Rural Migrant Labourers in Urban China: The Case of Shanghai," in Richard Anker Brígida García, Antonella Pinnelli (eds.), Women in the Labour Market in Changing Economies: Demographic Issues, Oxford, Oxford University Press, 2003. 
A newly built village in the outskirt of Tianjin where rural residents were transformed to urban residents, 2007. ๑ Fei Guo

(1)

$>$

status, the curve for rural migrants is the only curve above the overall Lorenz curve, whilst the curves for urban locals and migrants are both below the overall curve (see Figure 5). The Lorenz curves provide more or less the same patterns of income inequality within the three groups. There is a greater degree of income inequality within the urban migrant group, which is slightly greater than that of urban locals. Rural migrants are a relatively egalitarian group in terms of income. However, it is worth noting that urban locals have exclusive access to a variety of public services that are largely unavailable to migrants. For example, the income of urban residents cannot fully reflect the level of inequality, and tends to underestimate the overall inequality in cities. In Shanghai, it is estimated that salary-based income accounts for only 65 percent of the city's total income, whilst 25 percent is drawn from housing subsidies, healthcare, and education, and 10 percent from irregular or illegal economic benefits. ${ }^{(46)}$ Unfortunately, the estimation of this portion of income is beyond most current surveys and official statistics, as a unified system monitoring personal income and tax is unavailable. Our analysis only focuses on measurable monetary inequality. Similarly, we were unable to capture any "grey income" and non-monetary subsidiaries from employers or administrative institutions, as such information is difficult to collect and unreliable. Taking "grey income" and non-monetary subsidiaries into consideration, one could expect even greater inequality in urban China. The income gaps between urban locals and rural migrants would almost certainly be greater.

\section{Concluding remarks}

In the pre-reform era, Chinese urban society was essentially egalitarian, and differentials between social groups and sectors were insignificant. For the majority of urban residents, career mobility was restricted, but jobs were always allocated by local administrative authorities and the jobs tended to be largely secure. Although everyone's salary was low, various forms of social welfare and services were assured, in most of cases free of charge. The major divide in the pre-reform era, however, was between the rural and urban areas, described by some scholars as the Great Wall of Chinese society. ${ }^{(47)}$ The great majority of rural residents were entitled to none of these benefits and were tied to their farmland. Poverty, sometimes absolute poverty, prevailed in many rural areas, but only affected a small proportion of urban residents. This was largely due to the Chinese government's urban-centred development orientation in the first three decades after the founding of the People's Republic. The hukou system,
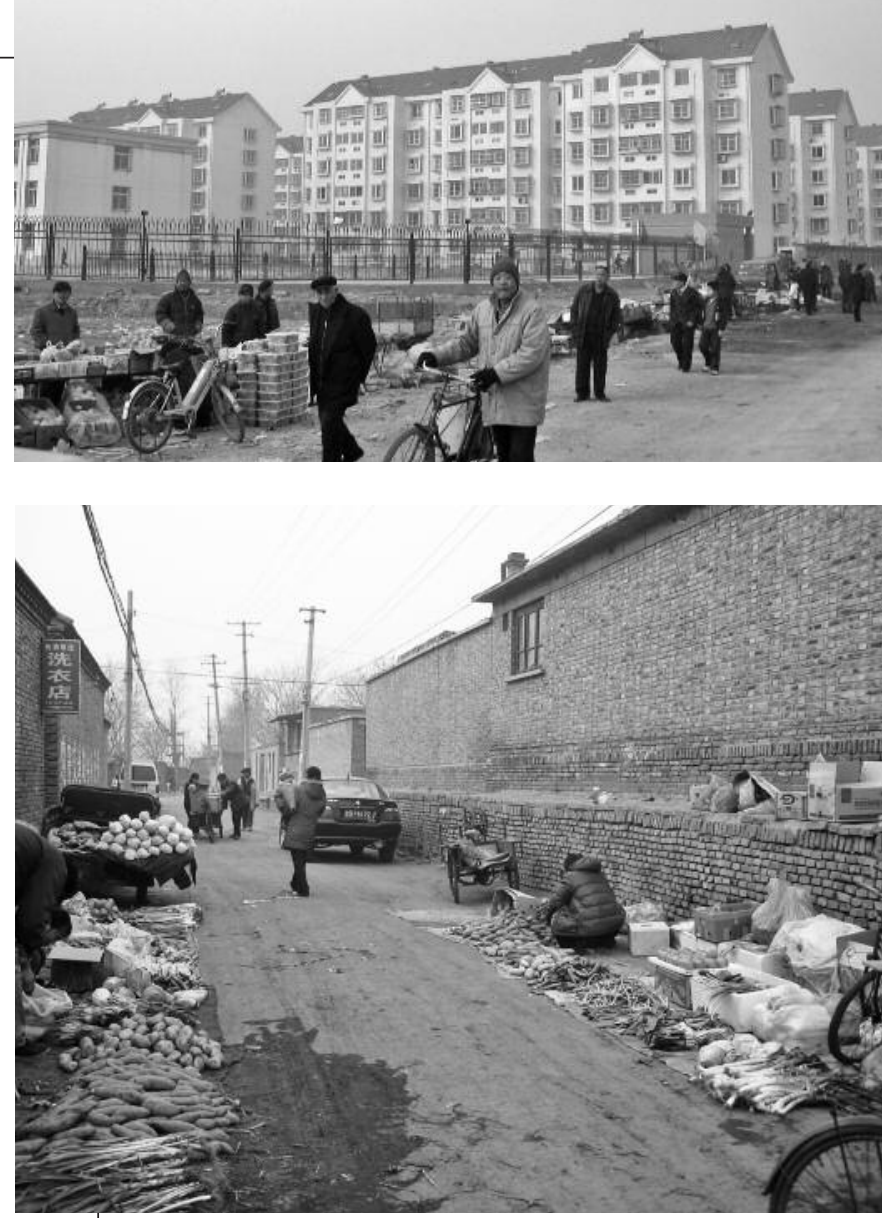

A village in the outskirt of Tianjin where cheap rental accommodation is available to rural migrants, 2007. () Fei Guo

which was first implemented in late 1950s, restricted labour mobility, especially mobility from the rural to urban areas. ${ }^{(48)}$ In the decades after reform, with gradual relaxation of the hukou policy and rapid development of the market-oriented economy, the country has seen an increasing number of migrants from both rural and urban areas, mostly moving toward large cities and coastal areas in search of better job opportunities and better income. The massive influx of ruralurban migrants has satisfied the demand for cheap labour in cities and fuelled three decades of rapid economic growth in a low-wage economy. In addition to attracting rural migrants, large urban centres, mainly located in the Pearl and Yangtze River deltas and the Beijing-Tianjin economic nexus, also attracted millions of urban migrants hunting for opportunities unavailable in their smaller hometown cities.

46. United Nations-Habitat, State of the World's Cities, 2008/2009, op. cit.

47. Feng Wang, "The Breakdown of a Great Wall: Recent Changes in Household Registration System in China," in Thomas Scharping (ed.), Floating Population and Migration in China: The Impacts of Economic Reforms, Hamburg, Institute of Asian Studies, 1997

48. Xiushi Yang, "Household Registration, Economic Reform and Migration," International Migration Review, vol. 27, no. 4, 1993, pp. 796-818. 
It is against this background that the results of this paper can be better understood. The economic history of many countries implies that serious urban poverty and significant inequality need to be frequently monitored in developing economies during the process of ideological transition, economic takeoff, and rapid urbanisation. This is not unique to China. The results of the present study, based on data collected from four of the most populated and developed cities in China, suggest that there are clear disparities in the labour market in large Chinese cities in terms of the means for obtaining jobs and the types of employment among urban residents, urban migrants, and rural migrants. Local urban residents, migrants from other cities, and migrants from the countryside tend to enjoy clearly different levels of public assistance in job searches. Migrants from the countryside tend to receive the least public assistance and tend to rely primarily on family members and friends for job searches. The results also indicate clear disparities in terms of the employment structure of the three groups; migrants from other cities tend to be much better off than migrants from the countryside in terms of types of employment. The results of this study also suggest that urban poverty and inequality in these cities were severe, with 6 to 17 percent of the total urban population living in poverty, depending on the definition of poverty lines, and that rural migrants were particularly affected. It is safe to say that rural migrants make up a significant component of the urban poor in large Chinese cities. However, official poverty relief programs in many cities only cover as little as 0.5 percent or no more than 2.8 percent of the poor, and exclude migrants, who are not registered in the local hukou system of the cities. The challenge is whether city authorities are willing or able to take rural migrants into consideration in their fight against urban poverty. In public debates and scholarly research, attention has often been focused on poverty in the rural areas and the inequality between rural and urban areas. There has been inadequate attention to urban poverty and inequality within various population groups within cities. The results of this paper strongly suggest that poverty and economic inequality are two important issues in urban China that deserve better understanding and more support from public resources. The finding that inequality among rural migrants as a group was less significant than among the other two groups does not necessarily mean that the issue is less severe, but rather that rural migrants as a group tend to be located at the bottom of the income spectrum.

This paper has addressed some important issues related to urban poverty and income inequality in large Chinese cities.
It has also raised a number of questions that warrant further study: for example, labour market segmentation as a determinant of wage levels, and the social welfare and security patterns for different hukou holders. The authors of this paper plan to carry out another study on the determinants for labour market disparities and income inequality using hourly wage-based poverty incidence and probability models. Empirical studies on social security entitlements and welfare program participation among urban local residents, migrants from other cities, and migrants from the countryside could also contribute to our understanding of poverty and inequality in large Chinese cities. In addition, more qualitative studies could enhance our understanding of the complex causes of poverty and inequality, and their consequences to families and communities.

$\begin{array}{ll}\text { Glossary } & \\ \text { danwei } & \text { 單位 } \\ \text { guoyou qiye gaige } & \text { 國有企業改革 } \\ \text { xiagang gongren } & \text { 下崗工人 } \\ \text { yuan } & \text { 圓 } \\ \text { hukou } & \text { 户口 } \\ \text { liudong renkou } & \text { 流動人口 } \\ \text { nongmin gong } & \text { 曹民工 } \\ \text { juweihui } & \text { 居委會 } \\ \text { dibao } & \text { 低保 } \\ \text { getihu } & \text { 個體户 }\end{array}$

